\title{
Effects of Compressive Stress on Internal Crack Formation of Continuously-cast Slabs*
}

\author{
By Hideyo KODAMA,** Eisuke NIYAMA,** Munehiro ENDO*** and \\ Tadashi NISHINO***
}

\begin{abstract}
Synopsis
Compression-casting where a cast slab is straightened under compressive stress along cast direction has been successfully applied to the conventional continuous casters, minimizing internal cracks. In a rotary type continuous caster, a cast slab is to be straightened just after leaving the mold, when shell thickness is small. In order to study effects of compressive force on internal crack formation of a cast slab of small shell thickness, a static casting experiment was carried out. It was shown that, by applying compressive force to a cast ingot, internal crack formation could be prevented.
\end{abstract}

\section{Introduction}

One of the major problems related with a recent increase of casting speed in conventional continuous casters is internal crack formation during straightening. For preventing crack formation several measures such as installation of more rolls, adjustment of roll alignment, continuous or multi-straightening, or optimum control of secondary cooling have been developed.

Compression casting where a cast slab is straightened under compressive force along cast direction is also reported.1) In compression casting, compressive force is generated by changing the speed of rolls before and after a straightening point, and is exerted to a cast slab whose shell has grown more than $50 \mathrm{~mm}$ thick. Tensile stress acting on the inner side of the shell is decreased by such compressive force, minimizing internal cracks in the cast slab.

In some types of continuous casters with a traveling mold a cast billet or slab is straightened with relatively small shell thickness, compared with the conventional continuous casters. For example, in the recently developed synchronized rotary type continuous casters for steel billets ${ }^{2}$ ) whose casting speed is two or three times faster than those of conventional continuous casters, a partially solidified billet is straightened just after leaving the mold, when the shell thickness is relatively small, typically from 15 to $20 \mathrm{~mm}$. Therefore, a cast billet is deformed with a large strain and high strain rate. ${ }^{3)}$

Considering stress distribution in a cast slab during straightening, compression casting which has been successfully applied to the conventional continuous caster is expected to be also effective in a rotary type continuous caster for slabs. In order to study effects of compressive force on internal crack formation of a cast slab with small shell thickness, a static casting experiment simulating solidification in the mold of a rotary type continuous caster was carried out. The results are presented and discussed assuming elastic deformation.

\section{Experimental Procedure}

In a rotary type continuous caster a slab with an arc shape is to be straightened. In the present study, however, an originally straight ingot was deformed into an arc shape for simplicity. A $4.5 \mathrm{~mm}$ thick steel plate mold was used instead of a water cooled mold so that the mold could be deformed together with the ingot. Figure 1 shows the mold structure. The mold was supported from outside by ribs made of steel flat bars, which were located separately with a distance of $70 \mathrm{~mm}$ or $110 \mathrm{~mm}$ along the mold height. This was to prevent mold bulging due to hydrostatic pressure of the poured steel and, at the same time, not to interfere with the deformation experiment.

The mold cavity was $50 \mathrm{~mm}$ in thickness, $200 \mathrm{~mm}$ in width, and $600 \mathrm{~mm}$ in height with a top riser of $50 \mathrm{~mm} \times 100 \mathrm{~mm} \times 150 \mathrm{~mm}$.

$46 \mathrm{~kg}$ steel of $0.2 \% \mathrm{C}$ was melted by an induction furnace. After adjusting sulfur content to $0.02 \%$, molten steel was poured through a tundish into the steel mold cavity. Table 1 shows the chemical compositions of steels. After a shell was formed, the cast ingot together with the mold was deformed into
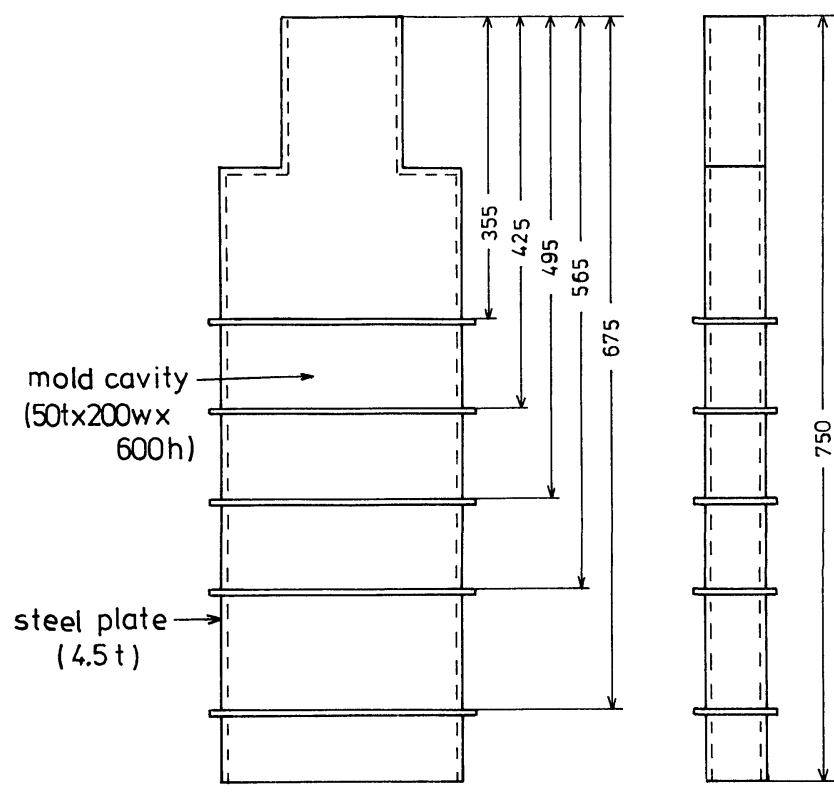

Fig. 1. Steel plate mold.

* Presented to the 102nd ISIJ Meeting, November 1981, Lecture No. S896. Manuscript received October 7, 1983. (C) 1984 ISIJ

** Katsuta Office, Hitachi Research Laboratory, Hitachi, Ltd., Horiguchi, Katsuta 312.

*** Hitachi Works, Hitachi, Ltd., Saiwai-cho, Hitachi 316. 
Table 1. Chemical composition of cast ingots.

\begin{tabular}{ccccc}
$\mathrm{G}$ & $\mathrm{Si}$ & $\mathrm{Mn}$ & $\mathrm{P}$ & $\mathrm{S}$ \\
\hline 0.18 & 0.41 & 0.44 & 0.031 & 0.015 \\
2 & 2 & 2 & 2 & $?$ \\
0.22 & 0.48 & 0.63 & 0.039 & 0.021 \\
\hline
\end{tabular}

an arc shape by horizontal movement of a pair of $100 \mathrm{~mm}$ diameter steel rolls driven by a jack. The distance between the rolls was $300 \mathrm{~mm}$, as shown in Fig. 2.

Compressive force along the height was applied to the cast ingot from $5 \mathrm{sec}$ prior to the start of bending deformation by pushing up the bottom steel stool by an air cylinder.

The movement of the rolls during bending was measured by a potentiometer attached to the jack. The bending force during deformation was measured by a load cell inserted in the space between the rolls and the jack. Direct measurement of the compressive force was difficult during deformation. Therefore, prior to a casting experiment calibration was made between the load cell output and a pressure guage of the air cylinder. The compressive force during deformation was estimated from the pressure gauge reading.

After a certain time bending was stopped and then, application of compression was stopped. After cooling the cast ingots sulfur prints of longitudinal sections were taken. The width and the length of cracks appeared on the sulfur prints were measured.

The superheating of molten steel was about $50^{\circ} \mathrm{C}$. The time from the end of pouring to the start of bending deformation was $80 \mathrm{sec}$ or $120 \mathrm{sec}$. The speed of bending rolls was $2.2 \mathrm{~mm} / \mathrm{s}$ or $4.4 \mathrm{~mm} / \mathrm{s}$, and the moving distance was $22 \mathrm{~mm}$.

A thermal analysis of a cast ingot in the steel plate mold was carried out by locating two PR30PR6 thermocouples at the distance of $300 \mathrm{~mm}$ from the mold bottom and at 10 and $25 \mathrm{~mm}$ from an ingot surface, respectively. Temperature was measured without applying bending and compression.

At the same time the outer surface temperature of a steel plate mold was also measured by CA thermocouples attached to a mold surface at the distance of $300 \mathrm{~mm}$ from the mold bottom.

\section{Results and Discussion}

\section{Solidification in the Steel Plate Mold}

Figure 3 shows the result of thermal analysis of a cast ingot and a steel plate mold. The time to reach the solidus temperature calculated from steel composition was $1.65 \mathrm{~min}$ at $10 \mathrm{~mm}$ from the ingot surface and $2.9 \mathrm{~min}$ at $25 \mathrm{~mm}$. The corresponding solidification rate constants were 7.8 and $14.7 \mathrm{~mm} / \mathrm{min}^{1 / 2}$, both smaller than those of the commercial rotary type billet caster. ${ }^{2)}$ This is due to the quick thermal saturation of the steel plate mold and subsequent slow cooling by radiation only, as shown in Fig. 3.

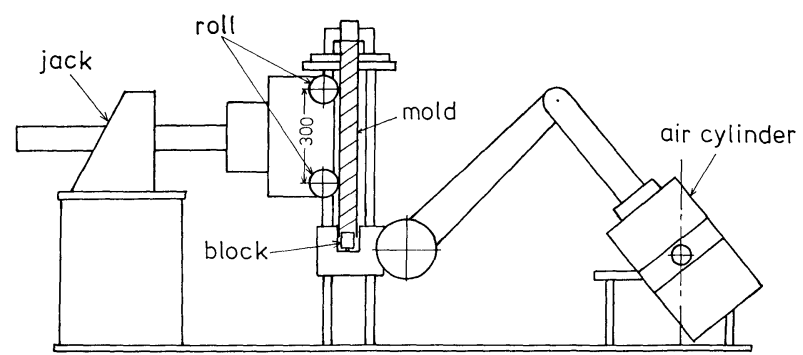

Fig. 2. Experimental apparatus.

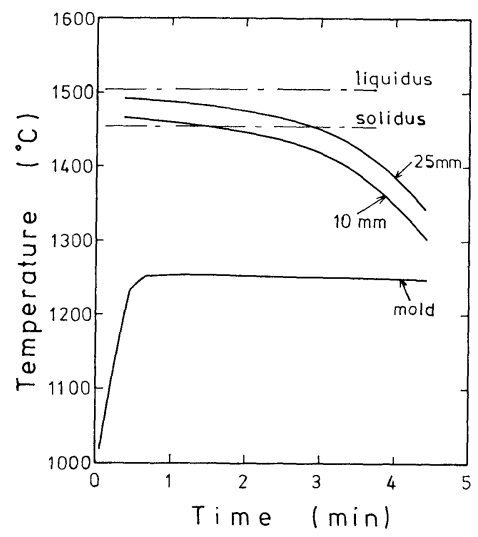

Fig. 3. Temperature/time profile of a cast ingot and a steel plate mold.

Table 2. Conditions of bending deformation and compression.

\begin{tabular}{c|rrrrl}
\hline $\begin{array}{c}\text { Heat } \\
\text { No. }\end{array}$ & $\begin{array}{rrrrr}t_{s} \\
(\mathrm{~s})\end{array}$ & $\begin{array}{c}t_{b} \\
(\mathrm{~s})\end{array}$ & $\begin{array}{c}v \\
(\mathrm{~mm} / \mathrm{s})\end{array}$ & $\begin{array}{l}F_{b} \\
(\mathrm{t})\end{array}$ & $\begin{array}{l}F_{c} \\
(\mathrm{t})\end{array}$ \\
\hline 1 & 80 & 10.0 & 2.26 & 2.27 & 0 \\
2 & 120 & 8.7 & 2.07 & 0.34 & 4.6 \\
3 & 80 & 10.0 & 2.20 & 1.40 & 2.0 \\
4 & 120 & 10.0 & 2.18 & 1.55 & 1.5 \\
5 & 80 & 5.3 & 4.57 & 3.05 & 0 \\
6 & 80 & 5.0 & 4.40 & 1.80 & 1.5 \\
7 & 80 & 5.0 & 4.40 & 1.48 & 2.5 \\
\hline
\end{tabular}

$t_{s}$ : time before bending $\quad F_{b}$ : bending force

$t_{b}$ : bending time $\quad F_{c}:$ compressive forec

$v:$ jack speed

\section{Bending Deformation and Compression}

Table 2 shows the conditions of bending deformation, the maximum bending force and the compressive force exerted to the cast ingots.

By comparing No. 1 ingot with No. 3, or No. 2 with No. 4 , it is noted that the bending force without the compressive force is larger than that with the compressive force. It is also seen that the bending force of No. 6 ingot with a moving speed of $4.4 \mathrm{~mm} / \mathrm{s}$ is larger than the bending force of No. 3 with $2.2 \mathrm{~mm} / \mathrm{s}$.

Photograph 1 shows the sulfur prints taken on the longitudinal section of each ingot. From these sulfur prints it may be noted that;

(1) The solidification structure consists of both columnar crystals extending about $10 \mathrm{~mm}$ from the 


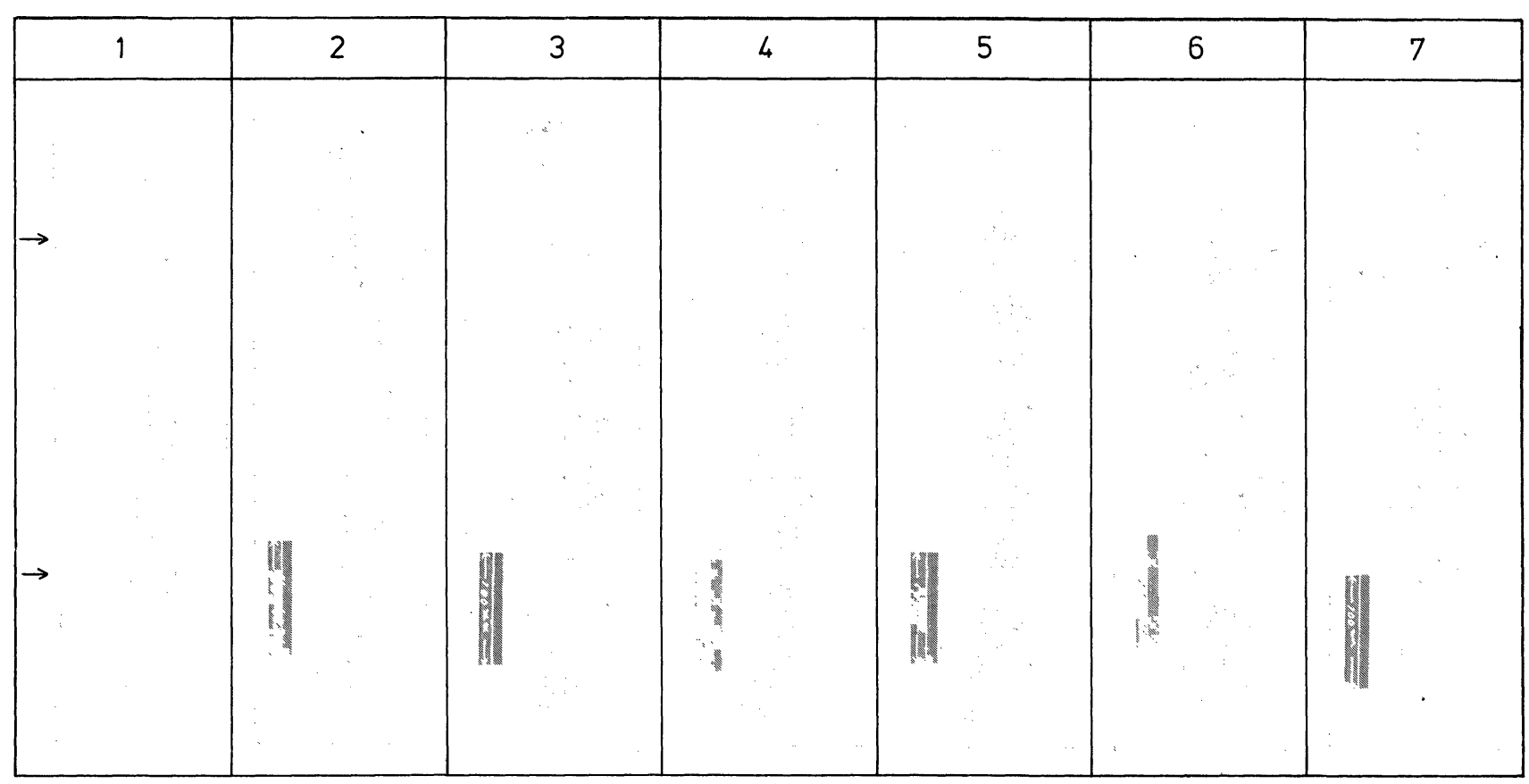

Photo. 1. Sulfur prints of longitudinal section of cast ingots.

ingot surface, and equiaxed crystals inside.

(2) Internal cracks form perpendicular to the ingot surface.

(3) Along the inner radius side of ingots there are no cracks within the interspace of the two bending rolls, although some cracks are observed around the regions where two bending rolls contacted with the mold.

(4) Along the outer radius side some cracks starting just below the ingot surface are observed.

(5) There are no cracks along the outer radius side of No. 2.

(6) Almost all cracks are filled with impurityrich metals.

From these observations bending deformation, when applied alone, appears to produce compressive stress along the inner radius side and tensile stress along the outer radius side except local deformation caused by the bending rolls.

In order to quantitatively evaluate the effects of bending deformation and compression on internal crack formation, strain, strain rate both of which were measured along the outer radius side and compressive stress were calculated.

The strain $\varepsilon(\%)$ was calculated by the following definition,

$$
\varepsilon=\frac{\frac{D}{2}-d}{R-\frac{D}{2}}
$$

where, $D:$ thickness of a cast ingot, $50 \mathrm{~mm}$

$d:$ shell thickness (mm)

$R$ : outer radius of a deformed ingot, measured on the sulfur prints (mm).

The shell thickness was calculated by using the experimentally measured solidification rate constant described in Section III. 1. For $80 \mathrm{sec}$, the time from the end of pouring to the start of bending, shell thickness is $9 \mathrm{~mm}$, and for $120 \mathrm{sec}$ shell thickness is $11 \mathrm{~mm}$.

The strain rate was calculated by dividing the calculated strain by bending time.

The compressive stress exerted to a cast ingot was calculated by dividing compressive force by the horizontal cross sectional area of a shell being formed when the cast ingot began to receive bending deformation.

Table 3 shows the calculated strain, strain rate and compressive stress together with the mean length and the maximum width of cracks observed on the sulfur prints.

When only bending deformation is applied, the mean crack length reaches as long as $6.0 \mathrm{~mm}$ (No. 1) or $5.6 \mathrm{~mm}$ (No. 5). On the other hand, when compressive force is exerted, the mean crack length and the maximum crack width tend to decrease.

The effects of applied compressive stress on the mean crack length and the maximum width of cracks are again shown in Figs. 4 and 5, respectively. Both the mean length and the maximum width are decreasing linearly with increasing the compressive stress.

No. 2 ingot with the bending condition of $1.8 \%$ strain, $2.07 \times 10^{-3} l / \mathrm{s}$ strain rate and $0.92 \mathrm{~kg} / \mathrm{mm}^{2}$ compressive stress has no cracks. Deformation condition of No. 2 is similar to those of No. 1, No. 3 or No. 4 except the compressive force. However, the strain of No. 2 is two times as large as that of No. 4, or is about $25 \%$ or $45 \%$ larger than those of Nos. 3 and 1 . This suggests that large compressive force along the height makes bending deformation easier than that without compressive force.

It is shown that bending deformation produces tensile stress along the outer radius side. By assuming 
Table 3. Results of measurement on internal cracks.

\begin{tabular}{c|cccccc}
\hline Heat No. & $l_{\text {mean }}(\mathrm{mm})$ & $W_{\text {max }}(\mathrm{mm})$ & $\varepsilon(\%)$ & $\dot{\varepsilon}(l / \mathrm{s})$ & $\left.\sigma_{a}(\mathrm{~kg} / \mathrm{mm})^{2}\right)$ & $\sigma_{c}\left(\mathrm{~kg} / \mathrm{mm}{ }^{2}\right)$ \\
\hline 1 & 6.0 & 0.8 & 1.24 & $1.24 \times 10^{-3}$ & 0 & 0.73 \\
2 & 0 & 0 & 1.80 & $2.07 \times 10^{-3}$ & 0.92 & 1.06 \\
3 & 5.5 & 0.3 & 1.45 & $1.45 \times 10^{-3}$ & 0.48 & 0.86 \\
4 & 3.4 & 0.6 & 0.91 & $0.91 \times 10^{-3}$ & 0.30 & 0.54 \\
5 & 5.6 & 0.7 & 1.29 & $2.43 \times 10^{-3}$ & 0 & 0.76 \\
6 & 5.0 & 0.6 & 1.18 & $2.36 \times 10^{-3}$ & 0.36 & 0.70 \\
7 & 3.2 & 0.4 & 1.30 & $2.60 \times 10^{-3}$ & 0.61 & 0.77 \\
\hline
\end{tabular}

$l_{\text {mean }}:$ mean crack length

$W_{\max }:$ maximum width of crack $\varepsilon:$ strain

$\begin{aligned} \dot{\varepsilon} & : \text { strain rate } \\ \sigma_{a} & : \text { applied compressive stress } \\ \sigma_{c} & : \text { calculated compressive stress }\end{aligned}$

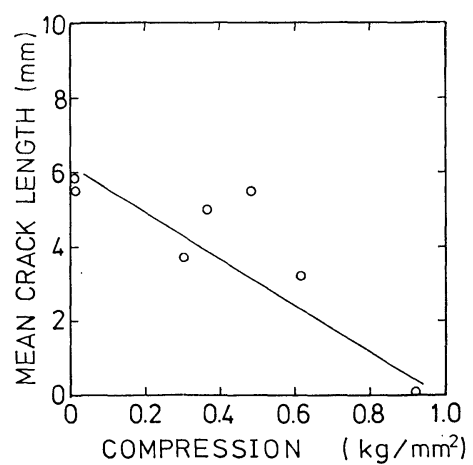

Fig. 4. Effect of compressive stress on mean crack length.

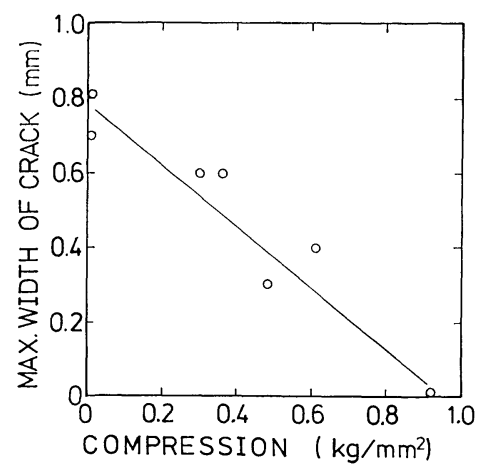

Fig. 5. Effect of compressive stress on maximum width of crack.

elastic deformation of a shell the bending stress is calculated and compared with the compressive stress.

Young's modulus $E$ of plain carbon steel is given in terms of temperature $T$ as ${ }^{4)}$

$$
E=\frac{5940}{T_{\mathrm{s}}-1134}\left(T_{\mathrm{s}}-T\right)^{2}\left(\mathcal{N} / \mathrm{cm}^{2}\right)
$$

where, $T_{\mathrm{s}}$ : the solidus temperature of steel.

The solidus temperature calculated from steel composition is $14566^{\circ} \mathrm{C}$. Referring to the temperature distribution and the reported crack formation temperatures $^{5)}$ the shell temperature is assumed to be $1400^{\circ} \mathrm{C}$ on the average. From these temperatures Young's modulus is $59 \mathrm{~kg} / \mathrm{mm}^{2}$. By using this value and the measured strain shown in Table 3, the tensile stress acting on the shell is calculated for each bending

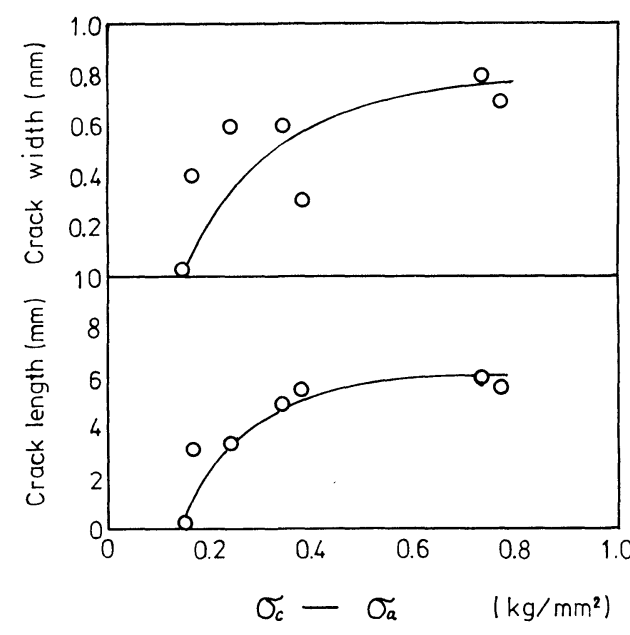

Fig. 6. Crack length and crack width vs. stress difference.

condition. The calculated stress is also shown in Table 3.

In order to quantitatively evaluate the effect of compressive stress on crack formation the maximum width and the mean length of cracks were plotted against the difference between the calculated tensile stress and the actually applied compressive stress. The results are shown in Fig. 6. As the stress difference decreases, both the width and the length of cracks become smaller. The stress difference corresponds to the effective tensile stress acting on a shell. Therefore, the critical tensile stress for crack formation is estimated to be $0.14 \mathrm{~kg} / \mathrm{mm}^{2}$.

\section{Conclusions}

In a rotary type continuous caster a slab is straightened under the small shell thickness. Therefore, internal crack formation can be predicted. In order to study the effects of compressive force on internal crack formation static casting experiments where a cast slab with a thin shell was bent under compressive stress along the height of a cast slab were carried out. It was shown that by applying compressive force internal crack formation was prevented. By assuming elastic deformation of a shell the tensile stress acting on a shell was calculated and compared with the applied compressive stress. The critical stress for internal crack formation was estimated to 
be $0.14 \mathrm{~kg} / \mathrm{mm}^{2}$.

\section{REFERENCES}

1) N. Yamauchi, Y. Uchida, T. Yamamoto, and H. Misumi: Seitetsu Kenkyu, (1978), No. 294, 62.

2) H. Kodama, E. Niyama, M. Horiguchi, T. Kimura and M. Endo: Trans. ISIJ, 23 (1983), 161.
3) E. Niyama, H. Kodama, T. Kimura, and M. Endo: Iron Steel Eng., 58 (1981), Aug., 38.

4) O. Pühringer: Stahl u. Eisen, 96 (1976), 279.

5) E. Niyama: Proc. of Japan-US Joint Seminar on Solidification of Metals and Alloys, Japan Soc. for Promotion of Science and National Science Foundation, Tokyo, (1977), 271. 